\title{
第20回 近畿神経病理検討会抄録
}

\author{
昭和63年10月 4 日（火）（道修町第一ビル $4 \mathrm{~F}$ ） \\ 世話人代表 堤 啓（枚方市民病院中検病理）
}

\section{トルコ鞍内 cystic tumor の一例}

関西医科大学 脳神経外科

河本 圭司, 小田 恭弘,

栗本 匡久, 松村浩

症 例: 57 歳, 男性.

30年前, 他院にて下垂体腺腫の診断で開頭手術を受け た. その後特変なく経過していたが，昭和63年 3 月頃よ り頭痛, 一過性発熱をきたし 内科入院. その後, 易疲 労, 体重減少, 多飲多尿, 両耳側半盲出現し, 同年 5 月 当科に入院した. 単純写上トルコ鞍の拡大を認め, CT では鞍内より視交又槽にかけて ring enhancement を示 す isodense mass を認めた（Fig. 1). MRI は T1．T2 強調画像とも high intensity を示した. 再発下垂体腺 腫の腫瘍内出血を考え，経蝶形骨洞手術を行ったが，鞍 内より pus 様の流出を認めた.

組織学的所見：基質としての膠原線維が主体を占め, 惰円形の核で細長い突起を有す線維芽様細胞が散在して いる。一部に比較的細胞密度の高い所はあるが，多くは

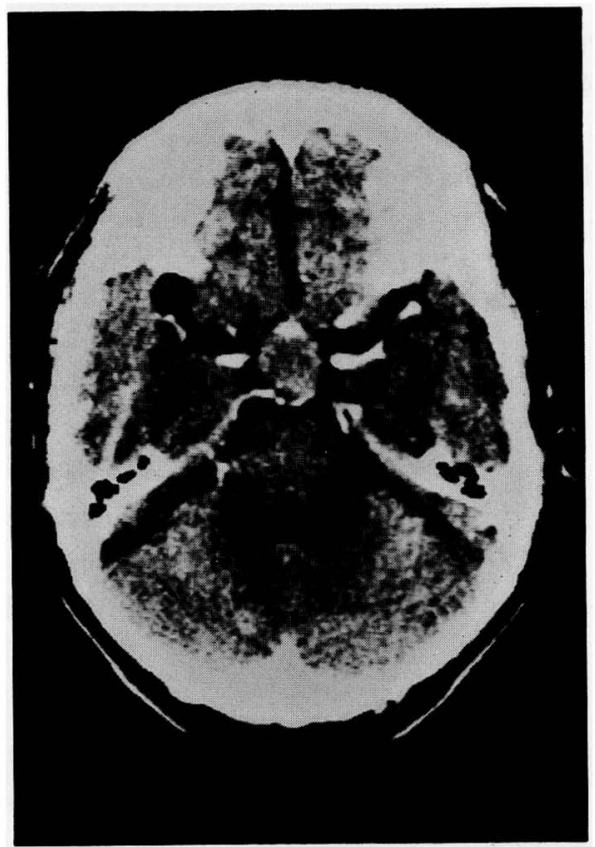

Fig. 1

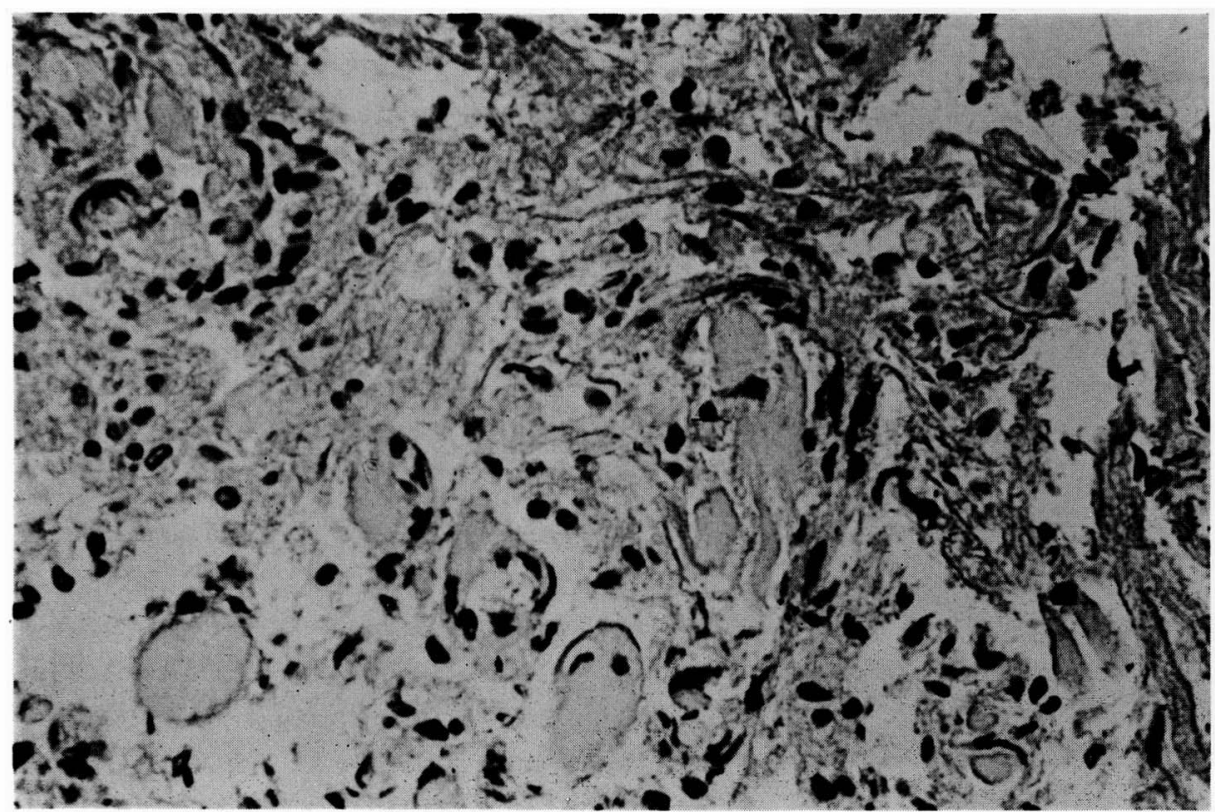

Fig. 2 
線維芽様細胞で，炎症細胞や腫瘍細胞とは断定しえな い. (Fig. 2) リンパ球様細胞も一部にみられるが, 炎症所見は見られなかった。 円柱上皮細胞もみられなか った，組織学的には陣旧性瘢痕組織で膿瘍壁組織とは断 定しえなかった。

Comments : 組織標本が小さいので彰断は困難との意 見が多かった. 症状が短期間に発現しているには炎症細 胞の浸潤がなく，以前の手術既往があることから更に診 断が困難になっている. cysticであることから Rathkes cleft cyst が疑われ，手術標本をより詳細に切片を作れ ば診断しえた例があったとの意見があり，再検討する必 要があると考えられた。

\section{蝶形骨洞原発の低分化型扁平上皮癌}

済生会中和病院 脳神経外科 角田 茂, 合田 和生 奈良県立医大 脳神経外科 柇 寿右 枚方市民病院 中検病理 堤啓

症 例 : 53歳, 女性.

主 訴 : 頭痛と複視.

現病歴: 昭和63年 8 月 5 日より頭痛が出現し， 8 月19 日より頭痛が増強するとともに呕吐が出現した． 8 月21 日，右上方注視時の複視を訴光はじめ， 8 月 22 日，当科 を受診して入院となった:

既往歴, 家族歴 : 特記すべきことなし.

入院時神経学的所見 : 意䇅清明で頭蓋内圧六進症状も なく，右動眼神経麻瘏のみ存在した.

頭部単純写：蝶形骨洞が不鮮明であった。

CT 所見: 単純 CT の coronal section で, トルコ鞍 底が上方に偏位し，蝶形骨洞内の mass lesion が描出さ れたが (Fig. 1)，造影 CT では軽度增強されるのみで あった。

脳血管写：両側 CAG を施行したが, tumor stain は 認められず，右内頸動脈の $\mathrm{C}_{4}$ portion の上方偏位のみ 認められた。

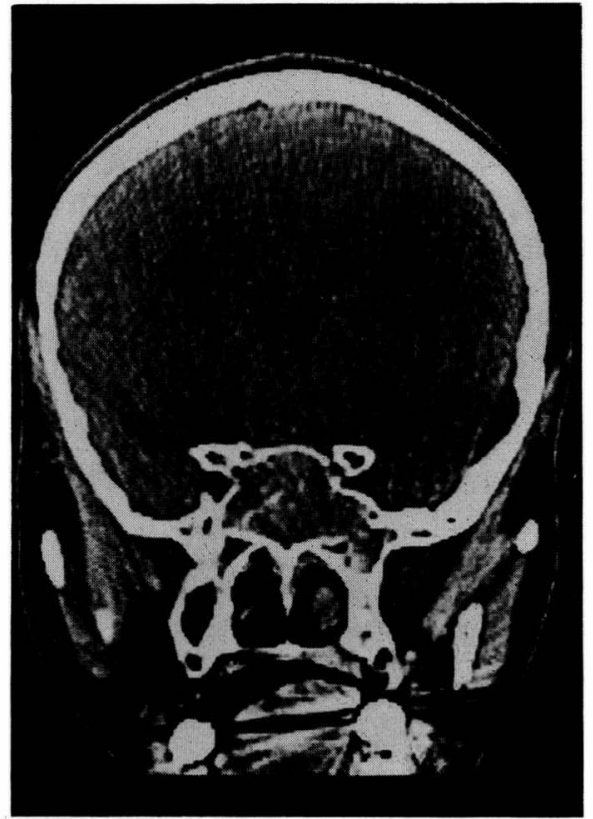

Fig. 1. Coronal section of plain CT

入院後経過： 8 月 30 日の早朝, 右眼が失明し, sphenoid muco-pyocele の䇏断のもとに, sublabial transseptal approach にて緊急手術を施行したが, 術前診断 とは違い, 易出血性の腫痬であった．9月 7 日，左眼も 失明.

光顕所見：繊毛上皮には扁平上皮化生が垫められ

(Fig. 2-a), 蝶形骨洞原発の扁平上皮癌を強く疑わし めた。 よく分化した部分では，keratohyalin granuleを 細胞質内に認める 顆粒細胞や角化が 認められた（Fig. 2-b). 未分化な部分では, 顆粒状の比較的明るい細胞 質をもつ細胞が密に増殖し, 核分裂像も豊富に認められ た（Fig. 2-c). 以上の組織所見より，低分化型扁平上 皮癌と診断した.

コメント：全身のガリウム・シンチ等を行ったが, 原 発巣は他になく、蝶形骨洞原発であることが確認され た．組織診断も，検討会にて異論はなかった．蝶形骨洞 原発の扁平上皮癌はきわめてまれであるが，急速に両側 失明となる臨床的特徵を持っているようである。 


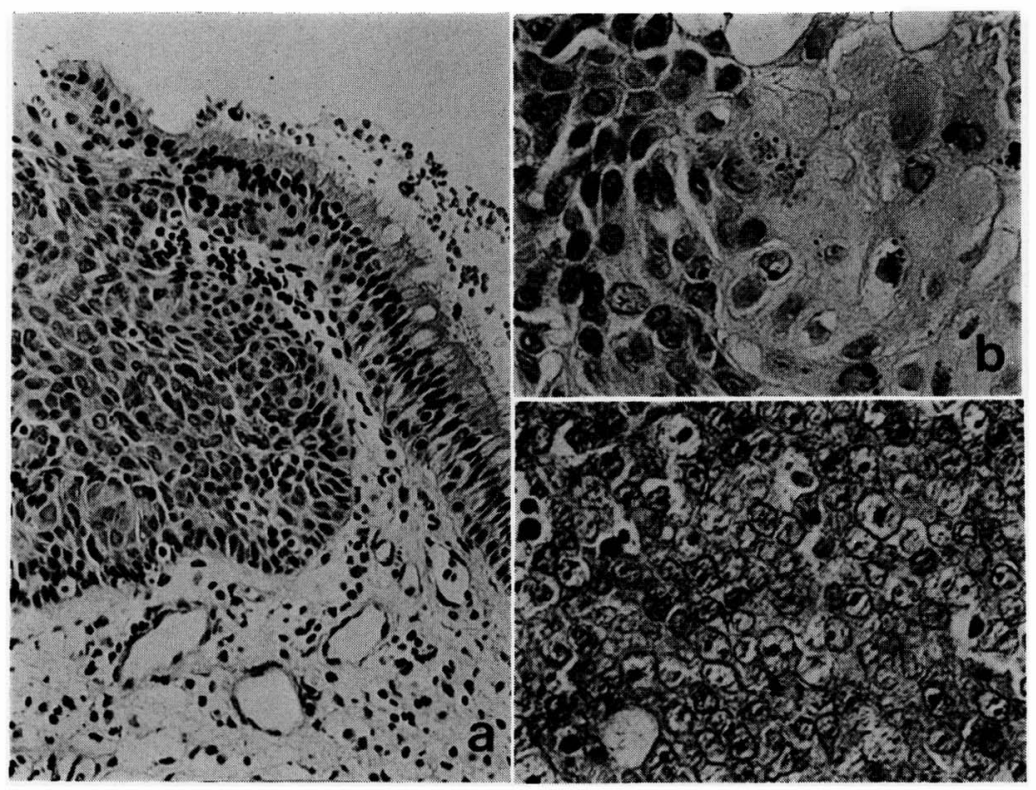

Fig. 2. Histological findings

a. Squamous metaplasia of the ciliatedaepithelium (H. E. $\times 100$ )

b. Well differentiated part (H. E. $\times 200$ )

c. Poorly differentiated part (H.E. $\times 200$ )

\section{Ghost tumor の一例}

大阪厚生年金病院 脳神経外科 病理検査科 長谷川 洋, 尾藤 昭二, 平賀 章寿, 小林 复

室 例 : 67歳, 男性.

主 訴: 頭痛, 左片麻痺.

現病歴 : 1986年夏より全身倦怠と体重減少があり12月 に頭痛と左片麻痺が出現したために入院した。

経 過: 入院後排尿, 嚥下, 構音障害, 眼振, 曈孔不 同が出現し左麻痖が悪化し意識低下をみたが, この時の CT, MRI, Angiogram には異常がなく 4 か月後の CT にて nasopharyngeal, midbrain, thalamus, lateral ventricular trigon, medulla などの multiple lesions を 認めた（Fig. 1)．ステロイドを投与してから， trigon の stereotaxic biopsy と palpebra tumor の摘出を行っ た. その後, 放射線と化学療法を行い, CT 上 tumor の消失を見たが, 症状の著明な改善を見ず肺炎を合併し 死亡した.リンパ節の腫脹は認めなかった。

病理所見：1）手術摘出標本 a) trigonal tumor : 壊 死を含む gliosis を伴った脳組織に血管の増生が目だち, 血管の周りには多数のリンパ球の浸潤が見られたが，腫
瘍細胞は存在しなかった（Fig. 1). b ) palpebral

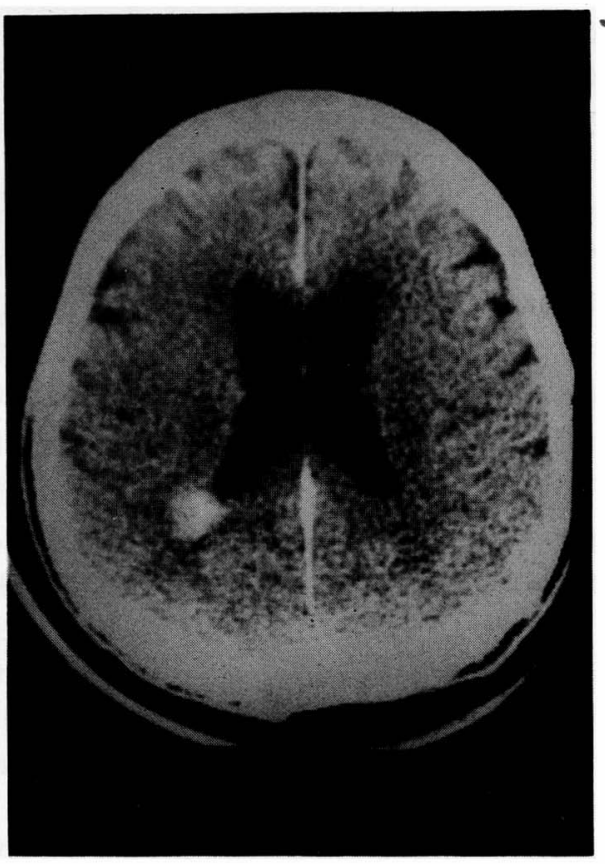

Fig. 1 Enhanced CT of trigonal tumor 


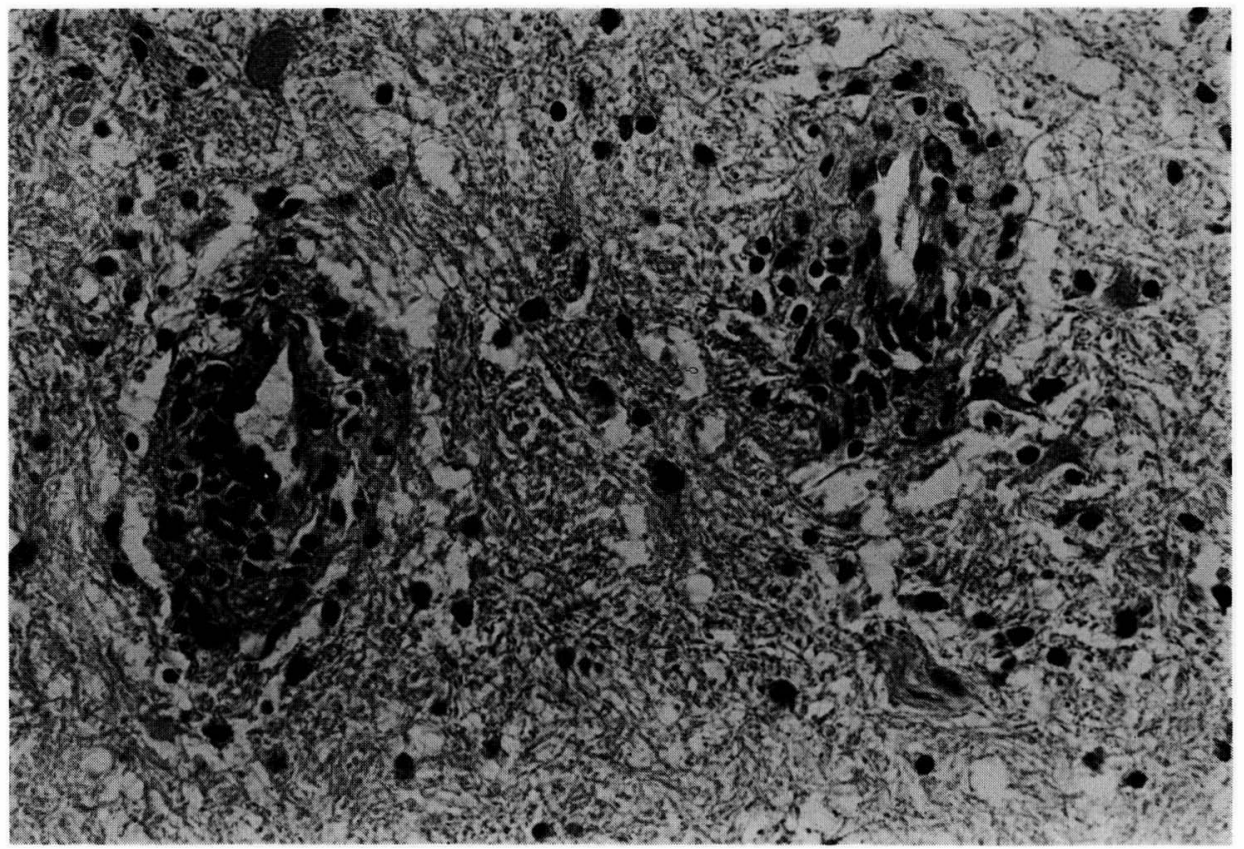

Fig. 2 Trigonal tumor $\mathrm{H} \& \mathrm{E} \times 400$

tumor : 小型の chromatin 飞富む胞体の少ない大型細胞 がび慢性密に配列しており， pleomorphism も見られ， malignant lymphoma と診断した. 2) 剖検: CT 上に 見られた中枢神経系の病巣はすべて変性壊死組織で腫瘍 紐胞を認めなかった. Comment : 本症例は生前, 死後の 組織検査にも拘らず, 中枢神経系から注腫瘍細胞が発見 できなかったが, malignant lymphoma であったと考え られる. Vaquero らは大きな lymphoma がステロイド のみで組織学的にも消失し, 再発するまで組織診断がで きなかった例を報告しこれを ghost tumor と呼えだ. malignant lymphoma の場合, 術前に脳浮腫のためにス テロイドが使用されると予期せぬような抗腫瘍効果によ り腫瘍が消失してしまい, biops yをしても腫瘍の病理組 織診断ができないことがあるので注意を要する．会員の 中でも同じ様な経験を持つ者がいた.

\section{傍トルコ鞍部に発生した chondrosarcoma の一例}

\section{大阪市立大学 脳神経外科 \\ 勝山 諄亮}

室 例: 39歳, 男性.

主 訴 : 複視.

現病歴: 昭和58年 11 月頃より左方視にて複視を自覚す るようになったが， 2,3 力月後には消失した。しかし，
翌年夏頃より全方向注視にて複視が出現するようになっ た. 昭和 61 年 4 月, 某院へ入院し左傍トルコ鞍部腫瘍を 指摘され， 7 月 4 日西全摘が施行された。術後，複視は

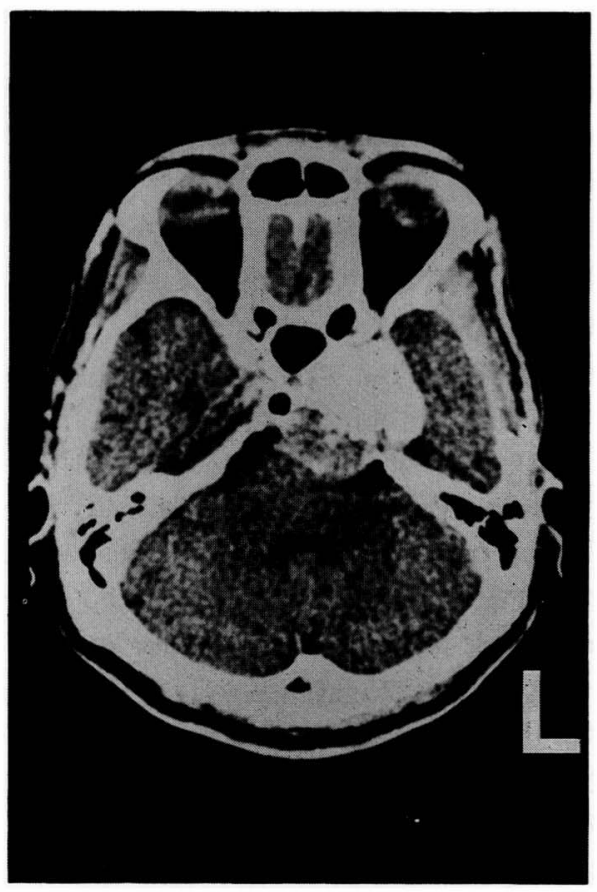

Fig. 1 造影 CT 
消失し 9 月に退院となったが，11月より複視のほかに， 眼䀫左下垂, 左視力低下, 顔面左半のしびれ感を生ずる ようになった．昭和 62 年 1 月，再入院となり，3月 9 日 に2 回目の手術が施行され, 術後 $50 \mathrm{~Gy}$ の放射線治療が 行われた。 その後, 著变なく経過していたが, 昭和63年 6 月 8 日，当院へ紹介された.

既往歴・家族歴：特記すべきことなし.

入院時神経学的所見（昭和63年 8 月23日）：左第 2 , $3,5,6$ 脳神経麻痺

CT 所見：左傍トルコ鞍部に值径約 $3 \mathrm{~cm}$ の腫瘍がみ とめられ，後方は橋前面にまで伸展していた。 その大部 分は石灰化とおもわれる high density area で占められ ていたが，腫瘍の後部は造影刜により中等度の増強効果 をうけた（Fig. 1)。
手術所見：腫瘍の大部分は石存化のために硬かった が, 後部はゼリー様で灰白色定呈し, 腫瘍は全摘出され た.

光顕所見：好塩基性をおびた基質のなかに軟骨性腫瘍 紐胞が親察されたが，比較的細胞密度は高く異型性がみ とめられた. また砂粒状の石灰沈着のほか骨組織の新生 をともなっていた（Fig. 2 ).

Comments : 病理組織診断, 特に悪性度の判定につい ての問題から供覧した. chondro-sarcoma と診断され るが悪性度については形態学的に評価が困難なことがあ り，一応は中等度悪性と考えられるとの意見が述べられ た. 予後については発生部位から考え，たとえ全摘出さ れても根治は期待できないとされた。

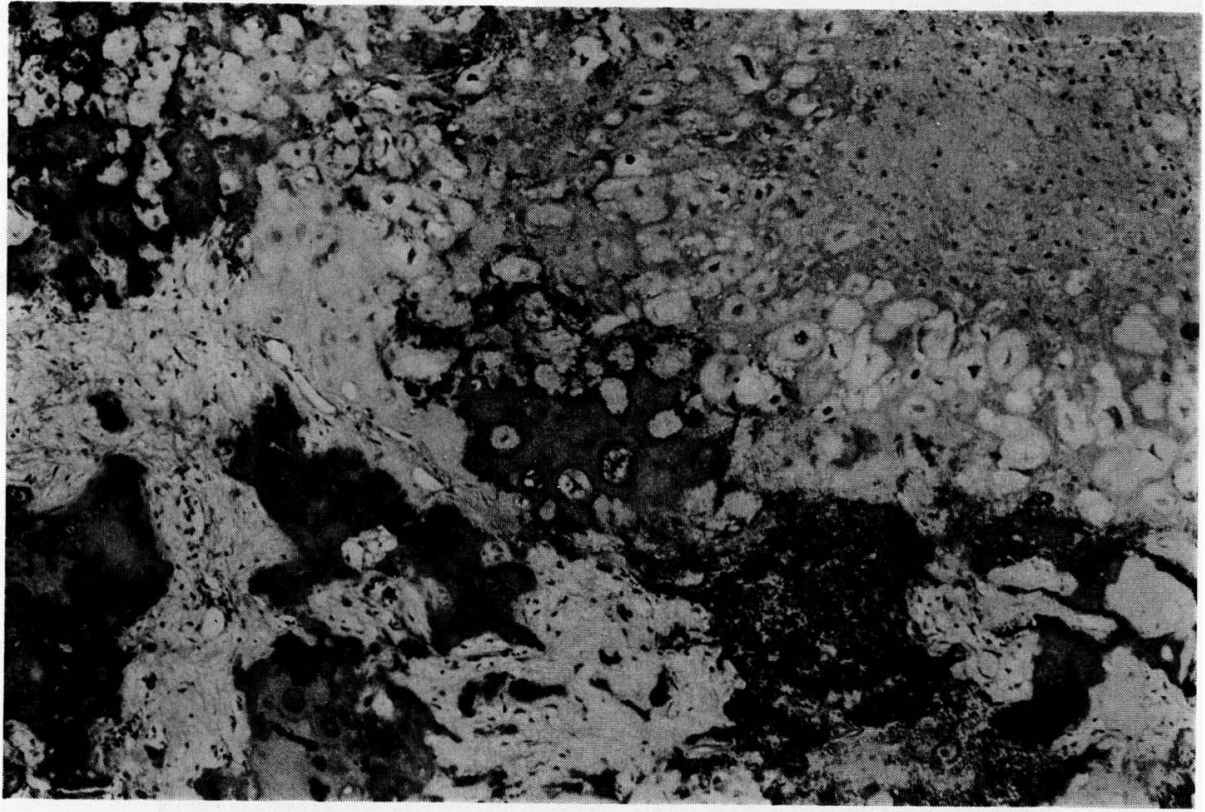

Fig. 2 ( $\mathrm{H} \& \mathrm{E}$ : 弱拡 $)$

後頭部頭皮下 hemangioendothelioma の一例

天理よろう相談所病院 脳神経外科

新阜 宏文, 鍋島 祥男,

室 例 : 生後 2 力月, 男巟.

主 訴 : 後頭部腫瘤.

現病歴：満期産. 正常分娩. 生下時には特に気付かな かったが, 徐々に左側後頭部に有痛性の腫瘤が出現し, 増大してきたため当科を受診した。
既往歴, 家族歴：特になし。

入院時所見：左側後頭部に約 $6 \times 4 \times 3 \mathrm{~cm}$ 大の有痛性 の皮下腫瘤を認める.腫瘍は弾性硬でその頂上付近では 真皮へ浸潤し，皮膚は暗赤色湾色している，成長，発 育正常.

頭蓋単純写 : 腫瘍値下の 後頭骨外板に わずかな erosionを認める. 明らかな骨破壊像, 骨形成像は認めな W.

CT 所見：腫りゅうは, homogenous に enhance され る. 


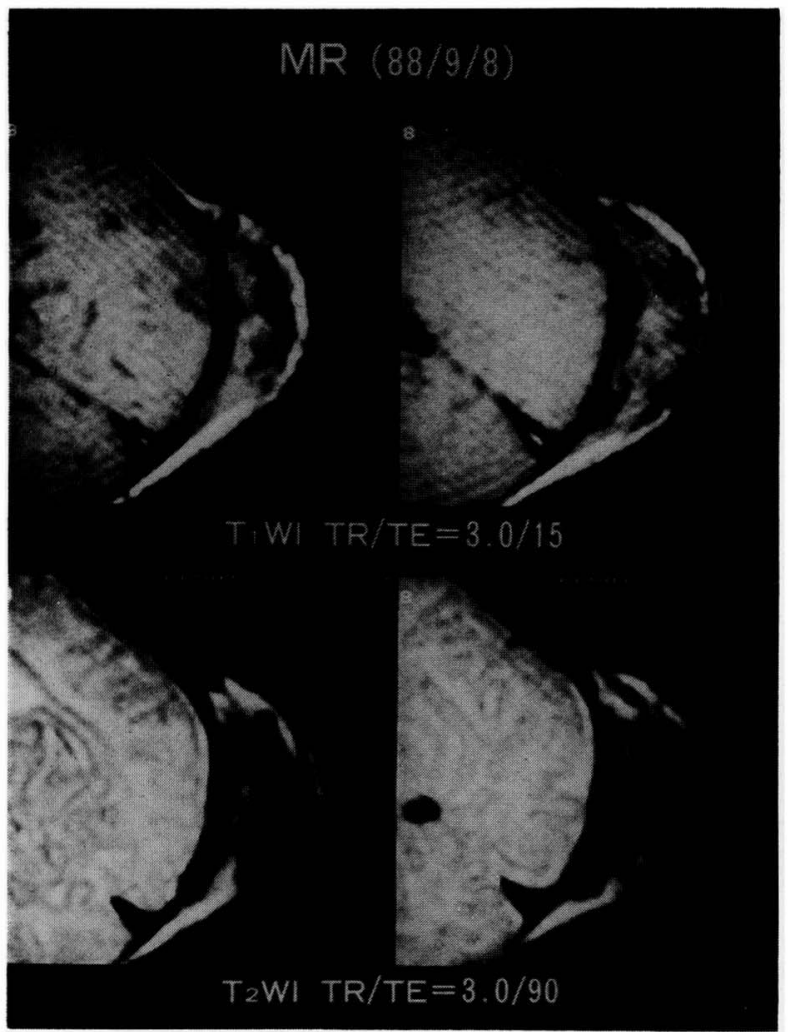

MRI 所見 (1.0T 超伝導 MRI)：T1 強調画像 では heterogenous に, T2 強調画像では low signal を示し, 一部は signal void を示す.（図 1 ) 脳血管写 : 後頭動脈から太い血管が腫瘍に分布 する. 腫瘍陰影, 早期静脈造影はみとめない.

手 術: subperiosteal に腫瘍を涂離し, 全摘 出した。

腫瘍は暗赤色を示し, 皮膚全層と皮下の組織に 浸潤し，周囲の結合織の肥厚も認められた。

光顕所見：異形成の少ない腫瘍細胞が massive に集塊を形成する部分と多層の壁をつくり管 腔構造をとる部分とが見られた．Factor VII染色で は明らかな染色性は認められなかった（reticulin 染色では reticulin fiberで境界された net-wrok の中に腫瘍細胞が多層に集まった管腔壁を認め た.）(図 2 )

Comments : この腫瘍は臨床経過からはいわゆ る, juvenile hemangioendothlioma が疑われた が，組織学的に， sarcoma との鑑別が 問題とな った. わずかだが, FactorVIII染色で染まっている との指摘も有り, 後ほど行った reticulin 染色で hemangioendothelioma と診断した.

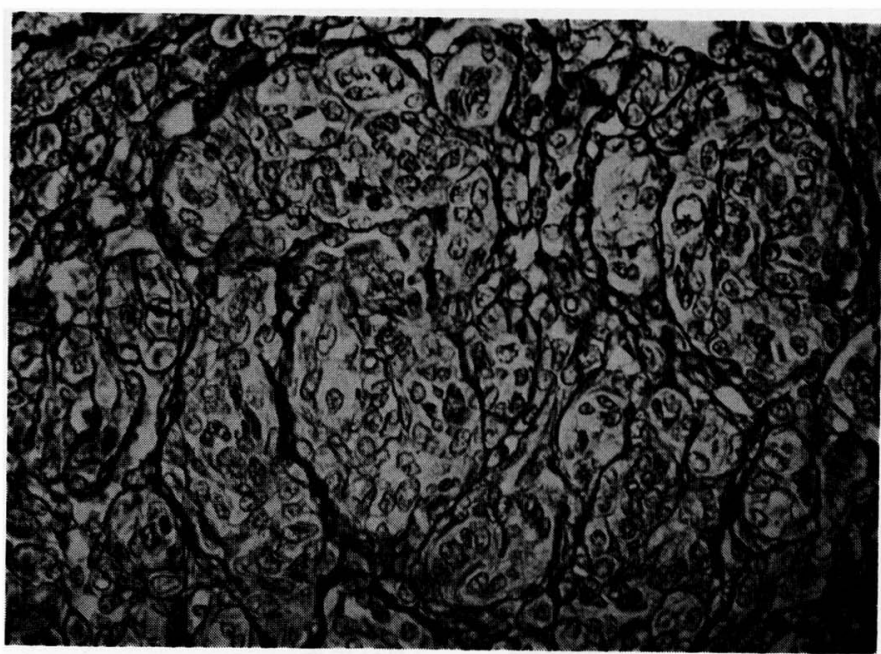


right parasellar lesionに発生した組織診断困難な脳 腫瘍の一例

大阪労災病院 脳神経外科 臨床病理科 馬淵英一郎, 狩野 光将, 辻村 俊

室 例 : 36歳, 女性.

主 訴：呕気, 呕吐, 頭痛.

現病歴：昭和63年 2 月頃より頭痛出現する。呕気，呕 吐と共にしだいに頭痛頻回にみられるようになるも妊娠 中（初産，妊娠 4 ケ月）の為のものと放置していた， 6 月20日，呕吐頻回に出現し某病院に救急入院する，その 時, CT 検査にて脳腫場が疑われ 6 月 23 日当院脳神経外 科に入院する。

既往歴，家族歴：特記すべき事なし。

神経学的所見：左同名半盲, うっ血乳頭

頭部単純写真：特記すべき事なし.

CT 検査 : rt. parasellar lesion に一部石灰化を伴う isodensity mass を認め, 造影戍にてほぼ均一に増強さ れた。 (Fig. 1)

脳血管造影：総頸動脈撮影動脈相に於て meningohypophyseal trunk main feeder とする異常血管を認め たが，静脈相に於て明らかな tumor stain は認めなか った.

手術時所見：腫瘍は約 $6 \times 6 \times 4 \mathrm{~cm}$ で周囲組織とは境

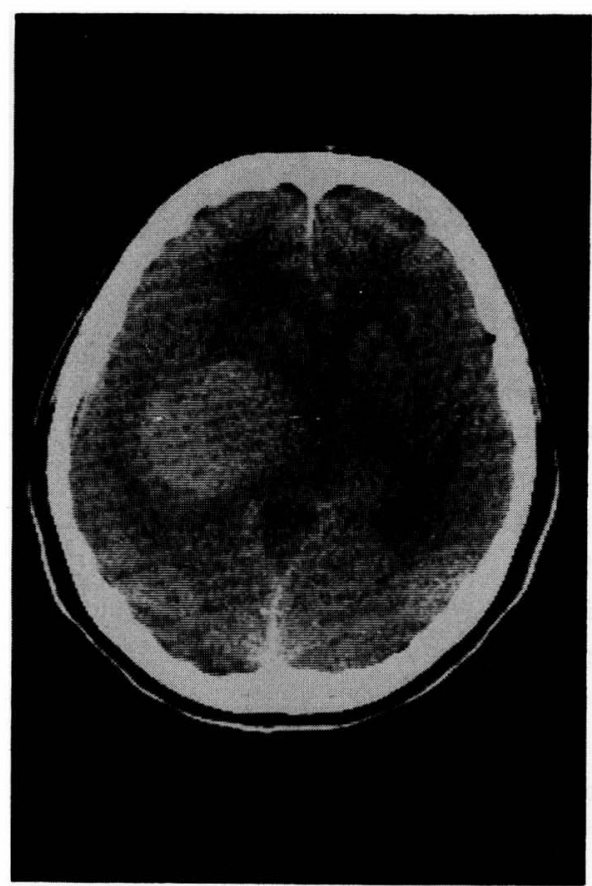

Fig. 1 Enhanced CT

界明瞭で encapsulated されていた. sphenoidal ridge と の attachment は認められなかった。

光顕所見 : 腫瘍は胞体の豊かな大型の細胞と紡錘形の

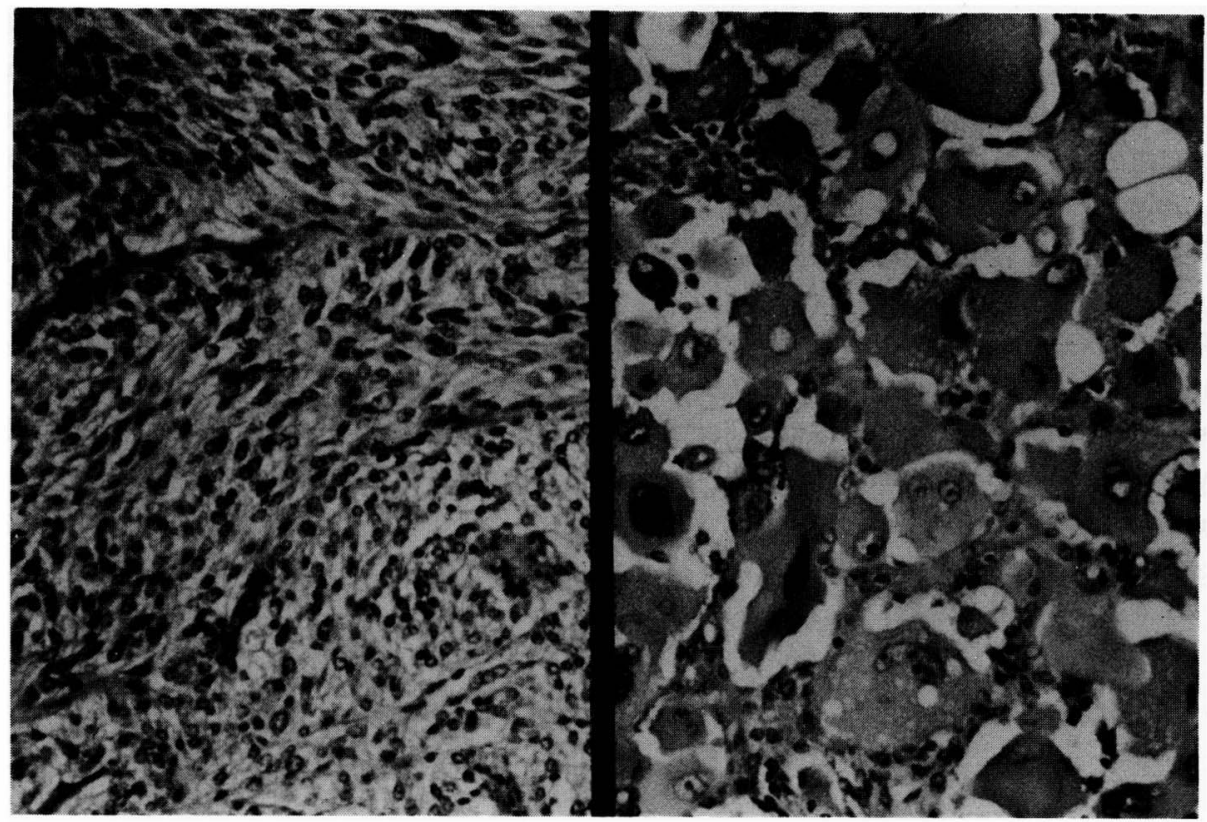

Fig. 2 H. E. 染色 $\times 100$ 
細胞から構成される. 大型の細胞は bizzare な核, 時に は2核あるいは多核を有し核小体も明膫である。胞体は vesicular で lipid を含有する.これらの巨細胞は個々 にあるいは数個集合している. 一方，紡錘形細胞は類円 形の核をもち胞体はそしく束状に直走あるいは交叉状に 配列する. 両者の間には移行像はみられるものの境界は 明膫である. 石灰化巣が散見される. mitosis や壊死は みられない. GFAP 染色では紡錘形の 細胞は陽性なる も巨細胞は陰性であった（Fig. 2)

Comments : この症例は臨床的に meningioma が疑わ れた. しかし, 組織学的には giant cell が顕著な特徵 的な像が混在し, meningioma 様の紡鏵形細胞は GFAP 染色陽性で, 且つ, 両者の間には移行像がみられ meningioma は否定的であった. 又, pleomorphic xanthoastrocytoma を疑ったが giant cell がGFAP 染色陰性の 点から一致しなかった. 壊死や mitosis がみられない点 から giant cell astroblastoma とも考えられなかった. astrocytoma と考えるべきとの comments を頂いたが詳 細は更に検討を要する余地を残した.

\section{Multifocal glioma の一例}

兵庫医科大学 脳神経外科
松本 強, 南 伸卓,
蒲 恵蔵, 谷 栄一

室 例 : 74歳, 右利き, 男性.

主 訴: 右不全片麻痺

現病歴：昭和 63 年 6 月中旬より右不全片麻痺出現し, 末日頃より感覚性失語室が出現し, 近医にて CT 異常指 摘され，当科紹介入院となった.

既往歴 : 13 年前, 左大腿骨骨折

神経学的所見 : 軽度混乱状態, 右不全片麻痺, 感覚性 失語症

神経放射線学的所見：CT では, 左前頭葉に perifocal edema を伴う ring enhanced mass と, 左頭頂葉にも ring enhanced mass が認められ, MRI では, $T_{2}$ 強調 画像において tumor は, high signal を示し, 明らかに 2つの tumor の連続性はみられなかった.（Fig. 1) 血管撮影では, 両者に tumor stain が認められた.

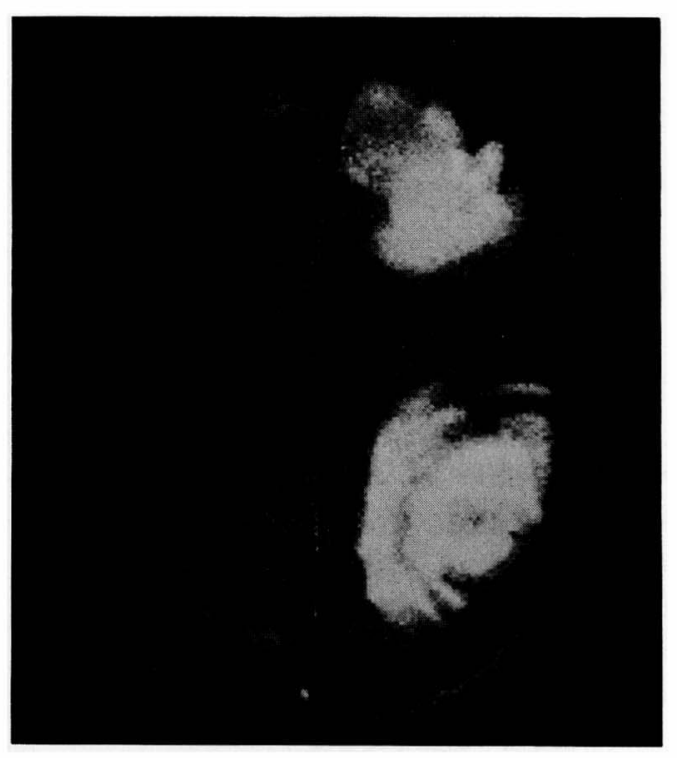

Fig. $1 \mathrm{~T}_{2}$-weighted MRI

手 術: 左前頭開頭にて, 腫瘍を全摘, 腫瘍は境界不 鮮明で，脳室との連続性はなかった．さらに，左頭頂側 頭開頭にて, 境界不鮮明な腫湯を全摘, やはり脳室とは 連続していなかった。

光顕所見：前頭葉の tumor は, 細胞密度も高く, 血 管増生も中程度にみられ, mitosis も散見される. 頭頂 葉の腫瘍は, より細胞密度が高く, 細胞質 /核比が大き い未分化な細胞がみられた（Fig. 2) 特殊染色では, GFAP は両者とも陽性であり, EMA (Epithelial membrane antigen), LCA (leucoyte common antigen) は 両者いずれも陰性であり，Multifocal anaplastic astrocytoma と診断した.

Comments : multifocal tumor の診断は, (1)腫瘍相互 間の連続性の否定, (2)血行性脳内転移の否定, (3)髄液に よる播種の否定を行なわなければならないが,この症例 では，いずれも否定された．ただ(2)の確定には，剖検に よる連続切片が必要である，検討会では，MRI の出現 により, 腫瘍の連続性が従来の CT に比べとらえやすく なり，今後このような症例が増えることが予想されると いう意見であった. 


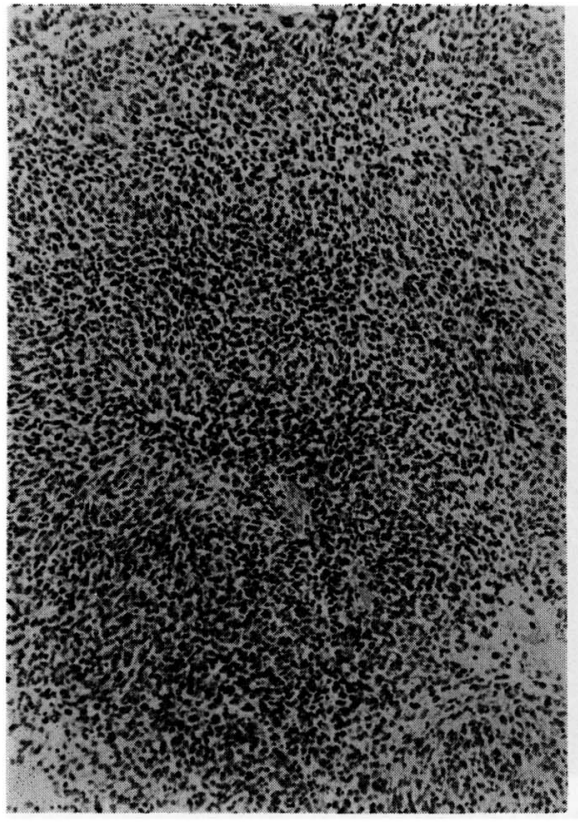

frontal tumor

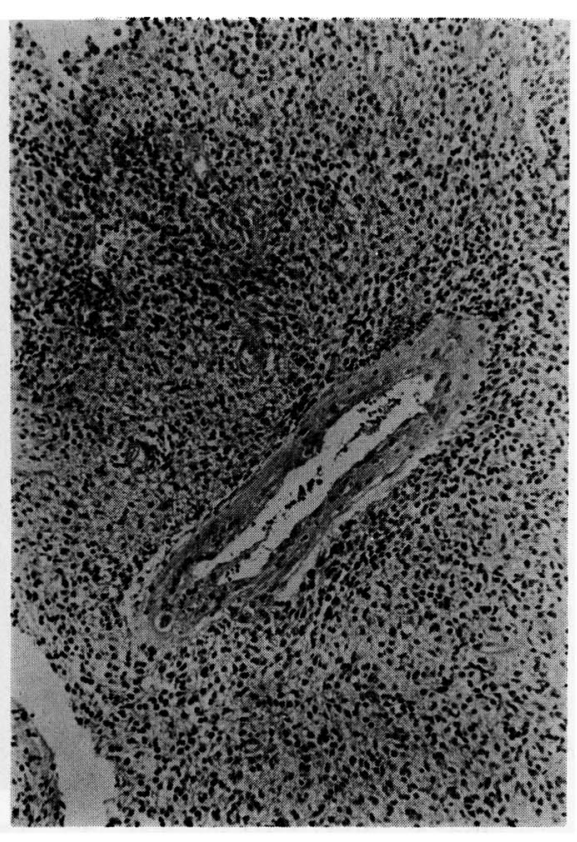

Parietal tumor

Fig. 2 H. E. 染色

画像診断上，覀性腫瘍を思わせた小脳星細胞腫の一例

京都大学 脳神経外科

東登 志夫, 西原 毅,
山崎 俊樹, 㐘池 晴彦

症 例: 15歳, 女性.

主 訴: 呕気, 呕吐を伴う頭痛および紧行障害.

現病歴：昭和62年春頃より呕気・呕吐を伴う頭痛を自

覚した．昭和63年 4 月頃から視力および歩行障害が出現 した．近医を受診し，CT 上異常を指摘され，6月10日 当科入院となった.

既往歴・家族歴： 7 歳洔, 虫垂切除術施行以外特記す ベきことなし。

神経学的所見：両側うっ血乳頭, 体幹運動失調

神経放射線学的所見 : CT では小脳虫部から第IV脳室 底にわたり, heterogeneous に enhance される占拠性 巨大腫瘍を認める. MRI ではプロトン強調画像で high signal intensity を示し, 腫瘍中央部に multi-lobular lesion 岁有する（Fig. 1 ）。脳血管撮影では数本の栄養 血管を有した腫瘍陰影を認める。

手 術: 後頭下開頭, 腫瘍全摘術. 小脳虫部より発生 した腫瘍と思われ，周囲脳組と織の境界は比較的明瞭 で, 腫瘍内に多房状の cyst を涩めた. 第IV脳室蓋部で は血管性に富み，境界不鮮明であった。

光顕所見 : 腫瘍は, 繊細で格子状の基質を背景とした 細胞密度の中等度に高い部分と, 新生血管あるいは内皮 紐胞の増殖を顕著に 認める部分から構成されていた。

GFAP, Vimentin 染色では腫瘍細胞は大部分陽性であ った．細胞分裂像は散見されるが，壊死像は認められな かった (Fig. 2 ).

Comments : 画像彰断上は, 脳室上衣腫, 骾芽腫, ある いは悪性膠腫等が疑われた。病理学的には, 第IV脳室蓋 部の腫瘍は細胞密度が高く, 新生血管あるいは血管内皮 細胞の増殖ならびに細胞分裂像を認め, 悪性所見を示唆 した。しかしながら，他の大部分では悪性像を認めず， fibrially astrocytoma (grade 2) と診断した. 


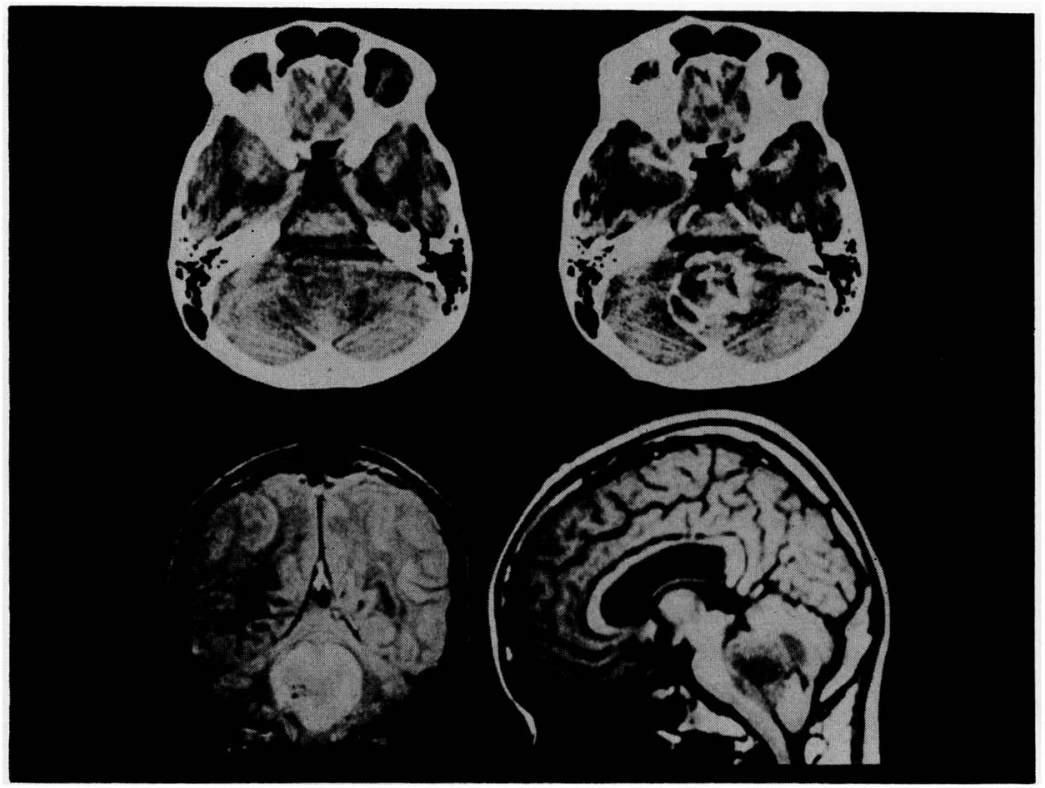

Fig. 1 上段 CT : 左, 単純, 右, 造影郕 (水平断)

下段 MRI : 左, プロトソ強調画像 (水平断), 右, $\mathrm{T}_{\mathbf{1}}$ 強調画像 (矢上断)

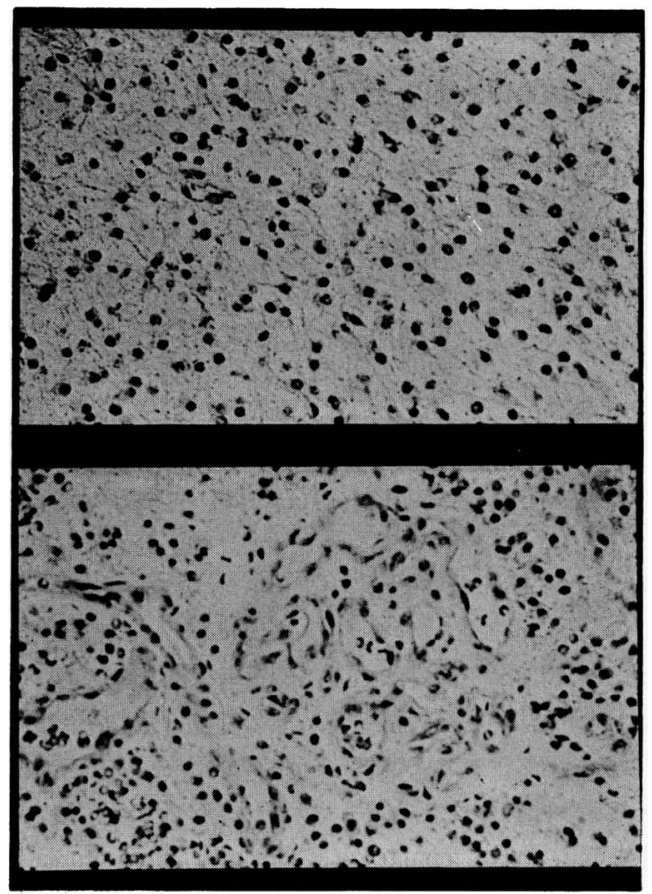

Fig. 2 上段（倍率, $\times 100)$ ：GFAP 染色陽性を示した充実性腫瘍部.

下段（倍率, $\times 100 ）$ 新生血管あるいは血管内皮細胞が多くみられた 第IV脳室蓋腫瘍部. 